\title{
Three Economist's Tools for Antitrust Analysis: A Non-technical Introduction
}

\author{
Russell Pittman
}

\section{Introduction}

The importance of economics to the analysis and enforcement of competition policy and law has increased tremendously in the developed market economies in the past 40 years. In younger and developing market economies, competition law itself has a history of 20-25 years at most-sometimes much less-and economic tools that have proven useful to competition law enforcement in developed market economies in focusing investigations and in assisting decision makers in distinguishing central from secondary issues are inevitably less well understood. While agencies and enforcers face a steep learning curve regarding these tools, companies and their attorneys and economic consultants are already using them to present agencies with sophisticated economic analyses purporting to demonstrate the lack of cause for concern regarding particular deals or practices.

This paper presents a non-technical introduction to three economic tools that have become widespread in competition law enforcement in general and in the analysis of proposed mergers in particular: critical loss analysis, upward pricing pressure, and the vertical arithmetic. The first is used primarily in the context of horizontal mergers for both market definition and the analysis of potential competitive effects from the merger, while the second and third are used primarily in the analysis of potential competitive effects, the second in horizontal mergers and the third in vertical mergers. All three are discussed extensively by now in the economics and legal literature, so that an introduction inevitably gives inadequate attention to some corollaries and complexities.

\author{
R. Pittman \\ Antitrust Division, U.S. Department of Justice, Washington, DC, USA \\ Kyiv School of Economics, Kyiv, Ukraine \\ New Economic School, Moscow, Russia \\ e-mail: Russell.Pittman@usdoj.gov
}

This is a U.S. Government work and not under copyright protection in the US; 


\section{Critical Loss Analysis}

Critical Loss Analysis (CLA) was introduced in 1989 (Harris and Simons 1989) primarily as a tool for market definition in merger investigations and has been used extensively since then in the analysis of both product markets and geographic markets. Subsequently it began to be applied, with appropriate amendments, to the analysis of competitive effects of mergers as well, with a focus on the analysis of the unilateral effects of mergers in markets with differentiated products. We will consider the two applications in that order.

\subsection{Critical Loss Analysis for Market Definition}

The standard methodology for market definition in merger analysis begins with the "hypothetical monopolist test": whether "a hypothetical profit-maximizing firm, not subject to price regulation, that was the only present and future seller of ... [a set of products] likely would impose at least a small but significant and non-transitory increase in price ('SSNIP') on at least one product in the market ..." (U.S. Department of Justice and Federal Trade Commission 2010). Even the broad implementation of this test requires the analyst to make a number of detailed choices and assumptions - some of which will be considered later-but for now let us make the exercise more straightforward by assuming that the hypothetical monopolist is restricted to charging a single price to all potential customers. (Note that this is a conservative assumption, in that it renders the analysis less likely to satisfy the test, since we are restricting the ability of the hypothetical monopolist to set the prices of each good at its profit-maximizing level.)

Algebraically, we assume that industry profits are currently set as:

$$
\Pi_{0}=\left(\mathrm{P}_{0}-\mathrm{C}\right) \mathrm{Q}_{0}
$$

where fixed costs are assumed sunk and irrelevant in the short term and marginal costs $\mathrm{C}$ are assumed constant, i.e. equal to average costs. The hypothetical monopolist of the industry would consider increasing price according to the following equation:

$$
\Pi_{1}=\left(\mathrm{P}_{0}+\Delta P-\mathrm{C}\right)\left(\mathrm{Q}_{0}-\Delta Q\right)
$$

and the critical issue is:

$$
\left(\mathrm{P}_{0}+\Delta P-\mathrm{C}\right)\left(\mathrm{Q}_{0}-\Delta Q\right) \gtrless\left(\mathrm{P}_{0}-\mathrm{C}\right) \mathrm{Q}_{0}
$$

Does the increase in profit from the price increase $\Delta \mathrm{P}$ on the sales that remain outweigh the reduction in profit resulting from the loss of sales $\Delta \mathrm{Q}$ ? Simple algebra reveals the "critical loss" of output that would make the monopolist indifferent: 
Table 1 A 4-firm provisional market

\begin{tabular}{l|l|l|l|l}
\hline Firm & Current output & Capacity & Price & Variable cost \\
\hline W & 100 & 105 & $\$ 50$ & $\$ 30$ \\
\hline $\mathrm{X}$ & 80 & 85 & $\$ 50$ & $\$ 30$ \\
\hline Y & 33 & 50 & $\$ 50$ & $?$ \\
\hline $\mathrm{Z}$ & 30 & $?$ & $\$ 50$ & $?$ \\
\hline
\end{tabular}

$$
\frac{\Delta Q}{Q}=\frac{\Delta P / P}{M+\Delta P / P}
$$

where $\mathrm{M}=\left(\mathrm{P}_{0}-\mathrm{C}\right) / \mathrm{P}_{0}$, the existing price-cost margin. If the loss of sales $\Delta \mathrm{Q}$ resulting from the increase in price $\Delta \mathrm{P}$ is higher than that which satisfies this equation, the price increase would not be profitable.

Of course, if we knew the elasticity of demand for the product, we would know the $\Delta \mathrm{Q} / \mathrm{Q}$ that would result from a given $\Delta \mathrm{P} / \mathrm{P}$, and no further analysis would be required to answer the market definition question. But let's assume that we are early in an investigation, without the data required for estimating such a parameter. Then the critical loss calculation described above serves to frame a very specific question: if price increases by a certain amount, how much would demand fall? And in particular, where would it "go"? Or, in the language of the CLA literature, now that we know the "critical loss", what would be the "actual loss"?

Consider now a hypothetical merger investigation, and the information that might be available early in the investigation to the analyst at the antimonopoly agency seeking to answer the market definition question. ${ }^{1}$ Suppose that the analyst has the following information, considered inexact but reasonably reliable.

Now suppose that firms $\mathrm{W}$ and $\mathrm{X}$ propose to merge, and our analyst wants first to analyze whether the product sold by these firms constitutes a relevant product market. Using the hypothetical monopolist test along with CLA, the question may be formulated as follows: would a hypothetical monopolist of this product raise prices by a SSNIP, say $5 \%$ ?

Using the prices and costs of the merging firms shown in Table 1, and assuming that these represent the prices and costs of a hypothetical monopolist, we see that a price increase of $5 \%$ would equal $\$ 2.50$, so that the monopolist would gain $\$ 2.50$ on each unit still sold, but would lose $\$ 50-\$ 30=\$ 20$ on each unit sale lost. Thus $\Delta \mathrm{P} /$ $\mathrm{P}=5 \%$ and $\mathrm{M}=\$ 20 / \$ 50=40 \%$. Then the critical loss for determining whether the price increase would be profitable is $\Delta \mathrm{Q} / \mathrm{Q}=5 /(40+5)=1 / 9=11 \%$. We therefore have the following question to investigate: if a hypothetical monopolist provider of this product raised price from $\$ 50$ to $\$ 52.50$, would sales be reduced by as much as $11 \%$ ? And in particular-focusing on the demand side, as is the practice in US enforcement - to what other products might consumers of these products switch?

\footnotetext{
${ }^{1}$ Examples of the use of critical loss analysis in US and EC merger investigations are presented in Langenfeld and Li (2001), O'Brien and Wickelgren (2003), Amelio et al. (2008), and Hüschelrath (2009).
} 
The relevant product market question asks to what degree customers will substitute away from the product in response to the price increase. Are there other products that are imperfect substitutes for this product but would become more attractive following a price increase? If the product is a consumer good, are consumers likely to be highly sensitive to price increases and to reduce their purchases of this good, allocating more of their budgets to other consumer goods, whether close substitute goods or unrelated goods? If the product is a producer good, are the firms that use this product as an input into the production of other goods able to substitute other inputs in the production process, and/or will they suffer their own losses of sales if forced to "pass through" this price increase of an input?

This is the basic version of CLA. It does no more and no less than focus the attention of the analyst on the precise (or somewhat precise, as will be discussed) question of how much substitution away from the products in the provisional product market would be necessary to defeat a potential anticompetitive price increase, and thus whether this choice of provisional product market represents the state of competition in the world as it exists or whether the provisional product market must be expanded to include the next closest substitute to constitute an actual market.

Once having identified the relevant product, a similar analysis would be applicable to the definition of geographic markets. To test whether the area that includes only the four firms in Table 1 is a relevant geographic market, for example, observe that the critical loss of $11 \%$ of their collective sales of 243 units is 27 units. If the hypothetical monopolist that raises price from $\$ 50$ to $\$ 52.50$ would lose sales of fewer than 27 units to producers outside of that area, the test is satisfied. If it would lose more than 27 sales, the area must be expanded to include those rivals to which purchasers switched. A number of variations and complications to this simple story should be considered.

\subsubsection{Implicit Elasticities}

In practice, the merging parties (and/or their lawyers and consultants) may argue that existing price-cost margins that look "high" suggest that a hypothetical monopolist would be unlikely to raise price much from its current level; after all, the argument may go, each unit lost in a reduction of output loses the entire existing margin-\$20 in our example_and the hypothetical monopolist would have to lose only a small amount of sales in order to regret its decision to impose a SSNIP.

However, as a theoretical matter, as Katz and Shapiro (2003), O'Brien and Wickelgren (2003), and Kaplow and Shapiro (2007) have pointed out, the estimated price-cost margin potentially contains information about the elasticity of demand facing the firms in the industry. According to the well-known Lerner Index, a profitmaximizing firm sets price where the price-cost margin equals the negative reciprocal of the elasticity of demand that it faces. In our example, the existing firms are earning profits of $40 \%$, which implies a firm-level demand elasticity of -2.5 . Industry-level demand elasticities are by definition smaller (in absolute value) than 
the firm-level demand elasticities of which they are made up. Thus a high operating margin, which implies a critical loss sufficiently small that merging firms may argue that it is unlikely to be realized, at the same time implies a small actual loss, since only firms facing a demand curve with relatively low elasticity could set prices and margins so high. ${ }^{2}$ As Katz and Shapiro (2003) summarize it, "A high gross margin implies a small critical loss. But a high gross margin also tends to indicate a small actual loss."

\subsubsection{Cost Estimates: Marginal vs. Variable, Constant vs. Fixed}

The profit maximization derivations on which both the CLA and the Lerner Index are based use the margin between price (or sometimes marginal revenue) and marginal cost to analyze the incentives of either individual firms or the hypothetical monopolist. In general, however, business firms do not calculate "marginal cost" in the ordinary course of business; rather, they usually calculate "variable cost", and though empirical analysts often use the latter as a proxy for the former, there are good reasons, both conceptual and practical, why the two are not likely to be identical.

First of all, from a pure measurement standpoint, Fisher and McGowan (1983) and Fisher (1987) demonstrate just how different the accountants' treatment of factors such as advertising, research and development, and other typical fixed costs can be from the economists' definitions. A separate measurement issue concerns the multiproduct nature of most firms; even the most careful business accounts may not be kept at the level of individual products.

Second, and more conceptually, as noted by Carlton and Perloff (2005) and Pittman (2009), true marginal cost as the first derivative of total cost includes at least implicitly a rental value of capital, and this term may become especially important as firm and/or industry production approaches capacity. An inquiry into the likely effect of a SSNIP that does not factor in the possibility of a rising marginal cost curve - which of course we observe in any intermediate microeconomics textmay underestimate the attractiveness to the firm of reducing output, and therefore too quickly reject the proposition that a hypothetical monopolist would find it profitable to increase price and reduce output. Simons and Coate (2014) argue the related point that firms making decisions regarding profit maximization in the long term will not generally base their thinking on short run marginal costs, even if measured accurately.

Werden (2005) and Baumann and Godek (2009) also note that the issue is broader than just the distinction between (theoretical) marginal and (measured) variable cost. Even if marginal cost is measured accurately, by variable cost or otherwise, the assumption that it is constant over the range of output choices of firms and the

\footnotetext{
${ }^{2}$ As the Horizontal Merger Guidelines point out in Sect. 2.2.1, a high operating margin may also be an indicator of existing coordination among the firms in the market.
} 
hypothetical monopolist may need to be examined. Approaching capacity limitations may be one factor; another may be differences in costs across firms, such that the hypothetical monopolist might not only raise price but also reduce output asymmetrically, focusing on cancelling production shifts at more expensive plants or even closing them down. To the extent that these complications lead the analyst to underestimate the marginal cost savings of lost sales, a price increase by the hypothetical monopolist will appear less profitable.

\subsubsection{The SSNIP}

As emphasized by Werden $(2005,2008)$, the details of the assumption of a SSNIP as usually practiced in the market definition exercise may be misleading in at least two ways, and these two may interact. First, the Guidelines ask whether a hypothetical monopolist would likely impose a SSNIP - a profit maximization questionwhereas the more common practice is to analyze whether the hypothetical monopolist could profitably impose a SSNIP - a break-even analysis. The latter interpretation has the distinct advantage of not requiring the analyst to make assumptions about the shape of the demand curve in the industry (Langenfeld and Li 2001), but it may affect the conclusion nonetheless.

In particular, a break-even analysis of a "small" price increase-say 5\% or 10\%, the usual choices-may miss the possibility that a firm or hypothetical monopolist facing customers with varying elasticities of demand might find it unprofitable to raise price by a small amount that keeps most customers in the market regardless of their elasticity of demand, but find it profitable to raise price a great deal more such that elastic demanders are priced out of the market while inelastic demanders pay the higher prices (Werden 2005, 2008). Rejecting the profitability of a small price increase can lead to a decision to expand the size of the provisional market, when examining the profitability of a larger price increase might lead to the conclusion that the original provisional market was correct after all.

The analyst who finds that the application of a break-even SSNIP leads to a rejection of the provisional market definition may therefore want to check the robustness of this result by asking whether there are customers of the product with significantly different elasticities of demand. Are there customers with demand so inelastic that selling to them only, at an even higher price, would be a profitable strategy for the hypothetical monopolist? At this point, of course, one is moving away from the appealing simplicity of the break-even test.

\subsubsection{Market Definition Is Not the Whole Story}

It perhaps goes without saying — but we will say it — that market definition is not the whole story in merger analysis. In particular, market definition, especially as practiced in the US, is focused on the demand side-purchaser preferences and switching behavior. But in many investigations the supply side-including the strategic 
responses of rival firms - may also be important. In EU practice, some of this supply-side analysis is included in the market definition exercise, while in US practice most of it is subsumed under the rubric of the potential for entry by other firms into the product and geographic market. ${ }^{3}$

In our example, on the supply side the analyst would be asking questions like the following: Are there producers outside of the market that might reposition themselves (either in product or geographic space) such that customers could easily switch to new suppliers without losing much in the way of either utility or efficiency? Are imports (from other domestic geographic areas or from foreign companies) poised to enter the market, and are there good reasons like transportation costs, tariffs, or quotas that would limit the scope or scale of their entry? If these imported products are not being purchased by customers now, there may be good reasons why they would remain unpurchased even following a SSNIP.

\subsection{Critical Loss Analysis for Unilateral Effects Analysis}

CLA is used not only in market definition but also in competitive effects (and especially unilateral effects) analysis. In this case the algebra of the derivation of the critical loss becomes a bit more complicated, and the introduction of an important new term is required.

In particular, let us return to the industry setting of Table 1, but now instead of analyzing whether it would be profitable for a hypothetical monopolist of the entire industry to increase price by a SSNIP, we analyze whether the merger of two firms, say firms $\mathrm{W}$ and $\mathrm{X}$, would provide the merged firm with the unilateral incentive to increase its own price only. We will simplify the analysis by considering the question of whether it would be profitable to increase the price of the good produced by firm W only; clearly the merged firm would consider the profitability of increasing the price of the goods produced by both firms.

Before the merger, firm $\mathrm{W}$ sets prices according to the same profit-maximization principles as the hypothetical monopolist, according to Eqs. (1)-(4), above. Prices were increased until just the point at which the loss in sales-both to other firms in the market and to the rest of the economy-outweighed the benefits of higher prices. After the merger, however, some of the losses from a price increase for the product of firm W are newly internalized by the firm - they are "recaptured" by firm X, now under the same control as firm W. Thus we have a new factor in the calculations, the

\footnotetext{
${ }^{3}$ See the Horizontal Merger Guidelines of the U.S. Department of Justice and Federal Trade Commission, August 19, 2010, at §4: "Market definition focuses solely on demand substitution factors, i.e., on customers' ability and willingness to substitute away from one product to another in response to a price increase or a corresponding non-price change such as a reduction in product quality or service. The responsive actions of suppliers are also important in competitive analysis. They are considered in these Guidelines in the sections addressing the identification of market participants, the measurement of market shares, the analysis of competitive effects, and entry."
} 
diversion ratio $\mathrm{D}_{\mathrm{WX}}$, the share of the sales of $\mathrm{W}$ that are lost as the result of a price increase for W that are "recaptured" by firm X (Willig 1991; Shapiro 1996, 2010).

Thus the profit-maximization question facing the merged firm as it considers whether and by how much to raise the price of good $\mathrm{W}$ is now:

$$
\begin{aligned}
& \left(\mathrm{P}_{\mathrm{W}}+\Delta \mathrm{P}_{\mathrm{W}}-\mathrm{C}_{\mathrm{W}}\right)\left(\mathrm{Q}_{\mathrm{W}}-\Delta \mathrm{Q}_{\mathrm{W}}\right)+\left(\mathrm{P}_{\mathrm{X}}-\mathrm{C}_{\mathrm{X}}\right)\left(\mathrm{Q}_{\mathrm{X}}+\Delta \mathrm{Q}_{\mathrm{W}} \mathrm{D}_{\mathrm{WX}}\right) \gtrless\left(\mathrm{P}_{\mathrm{W}}\right. \\
& \left.\quad-\mathrm{C}_{\mathrm{W}}\right) \mathrm{Q}_{\mathrm{W}}+\left(\mathrm{P}_{\mathrm{X}}-\mathrm{C}_{\mathrm{X}}\right) \mathrm{Q}_{\mathrm{X}}
\end{aligned}
$$

where $\Delta \mathrm{Q}_{\mathrm{W}} \mathrm{D}_{\mathrm{WX}}=\Delta \mathrm{Q}_{\mathrm{X}}$.

As with Eqs. (3) and (4), this translates into the critical loss of quantity W for the merged firm to raise price on good W (Langenfeld and Li 2001; Hüschelrath 2009):

$$
\begin{aligned}
& \Delta \mathrm{Q}_{\mathrm{W}} / \mathrm{Q}_{\mathrm{W}} \gtrless\left(\Delta P_{\mathrm{W}} / \mathrm{P}_{\mathrm{W}}\right) /\left[\left(\mathrm{P}_{\mathrm{W}}-\mathrm{C}_{\mathrm{W}}\right)+\left(\Delta P_{\mathrm{W}} / \mathrm{P}_{\mathrm{W}}\right)-\left(\mathrm{P}_{\mathrm{X}}-\mathrm{C}_{\mathrm{X}}\right)\right. \\
& \left.\quad \times\left(\mathrm{P}_{\mathrm{X}} / \mathrm{P}_{\mathrm{W}}\right) \mathrm{D}_{\mathrm{WX}}\right]
\end{aligned}
$$

Comparing Eq. (4) —as interpreted for a single profit-maximizing firm premerger - and Eq. (6) - the calculation for the firm after merging with a competitor-shows that the difference is the last term in the denominator on the right-handside - and that because this is the subtraction of the product of three positive terms, it will tend to increase the size of the critical loss that would make a price increase unprofitable. Note also something that we will return to in the next section: the increase in the critical loss for good $\mathrm{W}$ following the merger-and thus the increase in the incentive of its producer to increase price-is a positive function of (a) the margin earned on the second good X, (b) the ratio of the price of the second good X to the first good $\mathrm{W}$, and (c) the diversion ration of $\mathrm{W}$ to $\mathrm{X}$ - the percentage of sales of good W lost by a price increase that are recaptured by good X, now owned by the same firm.

\section{Upward Pricing Pressure}

Upward Pricing Pressure (UPP) might be considered a first cousin to the use of critical loss in the analysis of the unilateral effects of a proposed merger, with, among other wrinkles, a more direct focus on the potential efficiencies of the proposed merger and whether they are likely to outweigh the loss of competition in the price-setting of the merged firm.

In the previous section of the paper, we abstracted from the distinction between homogeneous and differentiated products, assuming that all firms charged the same price but that a single firm had the option to charge a different price. In this section we abandon this abstraction and embrace the distinction between these two types of goods that was such an important part of the revised Merger Guidelines in 1992. As Shapiro (2010) discusses at length, while the 1982 and 1984 Guidelines focused on the danger that a merger among competitors would increase the likelihood of 
collusion-either explicit or tacit—in the more concentrated market, thus focusing implicitly on homogeneous products, the 1992 Guidelines added a second focus on the likelihood that a merger among competitors producing differentiated products would provide incentives for the merged firm to raise price unilaterally, regardless of the behavior of competitors in response.

Thus a new emphasis was placed on the degree to which competing products were close or distant substitutes to each other-a concept implemented in the term that we introduced in the previous section, the diversion ratio $\mathrm{D}_{\mathrm{WX}}$ between two firms $\mathrm{W}$ and $\mathrm{X}$, the percentage of sales of good $\mathrm{W}$ lost in response to a price change for good W that are "diverted" to good X. A larger value for this diversion ratio $\mathrm{D}_{\mathrm{WX}}$ clearly suggested a merger that would be more troublesome from a competitive standpoint, ceteris paribus.

However, the 1992 Guidelines, along with the subsequent literature, simultaneously added a new focus on another term in the denominator of Eq. (6): the pricecost margin earned in the production of good X. If this margin were "high", especially vis-à-vis the margin earned in the production of good $\mathrm{W}$, the merged firm would be quite happy for sales of $\mathrm{W}$ to be diverted to sales of $\mathrm{X}$; not so much if the margin earned on the production of $\mathrm{X}$ were "low". Thus increased attention came to be focused on the product $\mathrm{D}_{\mathrm{WX}}\left(\mathrm{P}_{\mathrm{X}}-\mathrm{C}_{\mathrm{X}}\right)$, the value to the merged firm of sales of $\mathrm{W}$ that were diverted by the price increase for $\mathrm{W}$ to sales of $\mathrm{X}$, a parameter termed the "Gross Upward Pricing Pressure Index" (GUPPI) from the merger (Farrell and Shapiro 2010a; Moresi 2010). A corresponding term was calculated and considered for the merged firm's incentive to increase the price of good X.

\subsection{How to Use GUPPI?}

But how are we to interpret and use GUPPI? Any non-zero diversion from $\mathrm{W}$ to $\mathrm{X}$ accompanied by any non-zero margin on X would yield a positive value for GUPPI. One option would be to proceed with the CLA described in Sect. 2.2 above for the analysis of unilateral merger effects, plugging an estimated value for GUPPI into Eq. (6). Again, for an evaluation of the impact of the merger one would also perform the exercise in reverse, analyzing the incentives created by the merger for a unilateral increase in the price of $\mathrm{X}$, taking account of recapture in the sale of $\mathrm{W}$ through the corresponding diversion ratio $\mathrm{D}_{\mathrm{XW}}$.

A second option would be to use GUPPI to calculate the likely price impact of the merger directly, abstracting from any possible efficiencies from the merger. Farrell and Shapiro (2010b) and Hausman et al. (2011) provide formulas for doing so that rely on the assumptions of a linear demand curve and symmetric cross-price elasticities of demand along with estimated values for six parameters: the prices and margins for the two goods and the two diversion ratios.

For good $\mathrm{W}$, the post-merger profit-maximizing price change equals the following: 
Fig. 1 Value of diverted sales

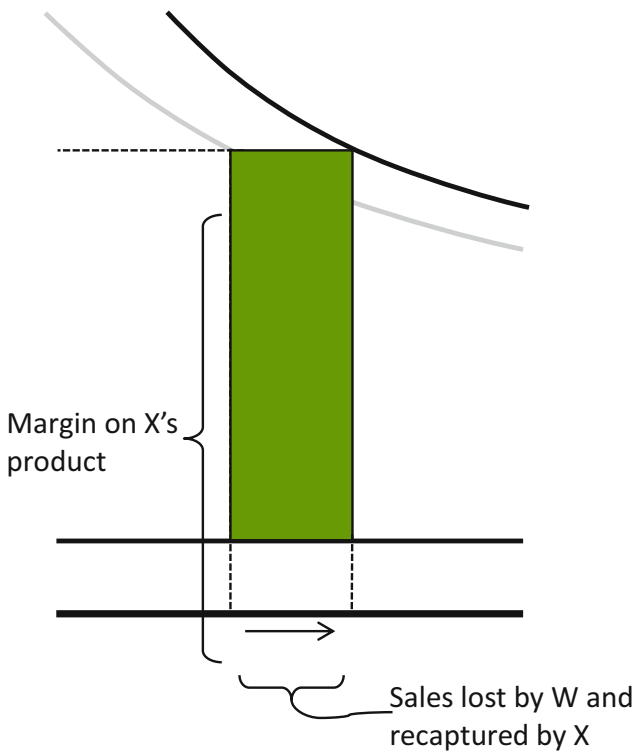

$$
\Delta P_{\mathrm{W}} / \mathrm{P}_{\mathrm{W}}=\left[\mathrm{D}_{\mathrm{WX}}\left(\mathrm{P}_{\mathrm{X}}-\mathrm{C}_{\mathrm{X}}\right)+\mathrm{D}_{\mathrm{WX}} \mathrm{D}_{\mathrm{XW}}\left(\mathrm{P}_{\mathrm{W}}-\mathrm{C}_{\mathrm{W}}\right)\right] /\left[2\left(1-\mathrm{D}_{\mathrm{WX}} \mathrm{D}_{\mathrm{XW}}\right) \mathrm{P}_{\mathrm{W}}\right]
$$

and correspondingly for good X. Again, what the formula makes most clear is one of the most important additions of the 1992 Guidelines to the 1982 and 1984 Guidelines: a significant incentive to increase price post-merger requires not only significant diversion ratios but also significant operating margins on the good or goods to which demand is diverted.

Figure 1 shows makes this point graphically. A price increase for the first good moves out the demand curve for the second good. The "value of diverted sales" is the rectangle that represents the product of (a) the volume of diversion from the first good to the second and (b) the margin earned on the second. Only if both the base and the height of the rectangle are of non-trivial magnitudes is the area of the rectangle "large".

Finally, as demonstrated in Werden (1996), information on diversion ratios and margins may be used to estimate the merger-specific marginal cost reductions ("efficiencies") that would be required to counterbalance the upward pricing pressure generated directly by the merger and so create a situation of unchanged pricing incentives for the merged firm.

\subsection{GUPPI to UPP}

A cousin of GUPPI is UPP, Upward Pricing Pressure, which adds estimates of postmerger marginal cost savings to the GUPPI calculations in order to calculate a 
measure of the "net" (of claimed or predicted efficiencies) incentives for the merged firm to increase prices. As suggested by Farrell and Shapiro (2010a) and then presented explicitly by both Farrell and Shapiro (2010b) and Schmalensee (2009), requiring now not only the assumption of linear demand curves but also estimates for the product-specific diversion ratios, prices and marginal costs, and claimed/ predicted reductions in marginal cost, the formula for merger UPP for good W is as follows:

$$
\begin{aligned}
\Delta P_{\mathrm{W}} / \mathrm{P}_{\mathrm{W}}= & \left\{\left[2 \mathrm{D}_{\mathrm{WX}}\left(\mathrm{P}_{\mathrm{X}}-\mathrm{C}_{\mathrm{X}}\right)-\mathrm{E}_{\mathrm{X}}\left(1-\left(\mathrm{P}_{\mathrm{X}}-\mathrm{C}_{\mathrm{X}}\right)\left(\mathrm{D}_{\mathrm{XW}}-\mathrm{D}_{\mathrm{WX}}\right)\right)\right]\right. \\
& \left(\mathrm{P}_{\mathrm{X}} / \mathrm{P}_{\mathrm{W}}\right)+\mathrm{D}_{\mathrm{XW}}\left(\mathrm{D}_{\mathrm{XW}}+\mathrm{D}_{\mathrm{WX}}\right)\left(\mathrm{P}_{\mathrm{W}}-\mathrm{C}_{\mathrm{W}}\right)-\mathrm{E}_{\mathrm{W}}\left[1-\left(\mathrm{P}_{\mathrm{W}}\right.\right. \\
& \left.\left.\left.-\mathrm{C}_{\mathrm{W}}\right)\right)\left(2-\mathrm{D}_{\mathrm{XW}}\left(\mathrm{D}_{\mathrm{WX}}+\mathrm{D}_{\mathrm{XW}}\right)\right]\right\} /\left[4-\left(\mathrm{D}_{\mathrm{XW}}+\mathrm{D}_{\mathrm{WX}}\right)^{2}\right]
\end{aligned}
$$

Again, there is a symmetric formula for the "upward pricing pressure" created by the merger for good $\mathrm{X}$.

\subsection{The Diversion Ratio}

Of course, a key requirement for making use of all these concepts is the estimation of diversion ratios. Unlike prices and (variable if not marginal) costs, these are not to be found in the account books kept by the companies. How, short of complex econometric estimation, might these be approximated by the competition agency analyst?

A straightforward approach, often treated as a sort of default option, is to use the shares of competitors in a candidate or provisional market to estimate diversion ratios (Willig 1991; Shapiro 2010). In our numerical example outlined above, if we consider firms $\mathrm{W}, \mathrm{X}, \mathrm{Y}$, and $\mathrm{Z}$ as the competitors in our candidate market, firms $\mathrm{X}$, $\mathrm{Y}$, and $\mathrm{Z}$ have $56 \%, 23 \%$, and $21 \%$ respectively of non-W sales. Since these market shares reflect the preferences and choices of existing consumers in the market place, we might assume that those same preferences would drive diversion in these proportions in reaction to a price increase on good $\mathrm{W}$. This approach is based on a number of assumptions (Willig 1991; Rybnicek and Onken 2016), including that we have an idea as to market definition - the latter a requirement that UPP analysis is designed in part to obviate (Farrell and Shapiro 2010a).

But there are often other good sources of information to guide the analyst in both evaluating the accuracy of market shares as indicators of diversion ratios and in judging how these estimates of diversion ratios might be adjusted to better reflect market realities. As Farrell and Shapiro (2010a) note: 
The diversion ratio might be estimated using evidence generated in the merging firms' normal course of business. Firms often track diversion ratios in the form of who they are losing business to, or who they can win business from. Consumer surveys can also illuminate diversion ratios, as can information about customer switching patterns (p. 18, footnote omitted).

In particular, interviews with, and documents supplied by, customers of the firms may yield subjective but informative information as to the particular qualities of differentiated products that make each a closer or more distant substitute for others as well as objective reports of past switching events and their rationales. In the latter respect, "natural experiments" may be especially informative: when product W became temporarily unavailable because of labor or transportation problems, what did its usual customers do in response? These additional sources of information can allow the analyst to calculate diversion ratios from an independent source or to better evaluate the diversion ratios estimated via market shares.

Finally, any estimates based on the within-market shares of diverted sales may be tempered by the recognition that some of the demand for good W will leave the market entirely in response to a price increase - thus each firm-level estimate may be multiplied by a factor that reflects the "aggregate diversion ratio"- the "fraction of the units that would be lost by an individual firm that are retained by the hypothetical monopolist" (Farrell and Shapiro 2010b).

\subsection{The Limits of UPP and GUPPI}

As noted above, both UPP and GUPPI may be used as indicators of the degree of competition likely to be lost from a merger; to provide a forecast of post-merger price increases by the merged firm; or to calculate the magnitude of merger-induced "efficiencies" necessary to remove the incentive for price increases following the merger. UPP and GUPPI, like critical loss analysis, are tools that focus attention on particular issues and factors that affect the profitability of a price increase by either a hypothetical monopolist (in market definition) or the merged firm (in unilateral effects analysis). ${ }^{4}$

That being said, it is also important to keep in mind that conclusions based on UPP and GUPPI — and CLA — are strongest when the analyst has also assessed the validity of the underlying assumptions as well as other questions not directly addressed by these tools. As one important example, none of these takes account of the possibility of the reactions of other firms to the possible price changes imposed by the merged firm. Such reactions could render the proposed merger either more or less harmful to competition and customers. For example, if competitors "accommodated" post-merger price increases by increasing their own prices, the merger harm

\footnotetext{
${ }^{4}$ Baltzopoulos et al. (2015) discuss the use of UPP in five recent cases reviewed by Konkurrensverket, the Swedish Competition Authority.
} 
would be increased. On the other hand, if competitors repositioned their products in order to be closer substitutes to the products of the merged firm, that could increase the diversion to rivals, reducing the incentive for price increases and the harm to competition from the merger (Pakes 2010; Cheung 2016). ${ }^{5}$

\section{The Vertical Arithmetic}

Consider a proposed merger that is vertical rather than (or in addition to) horizontal. Consider, for example, a proposal by a manufacturer to purchase its supplier of a crucial raw material. How much should the antimonopoly agency be concerned about a loss to competition? In particular-though, as we will discuss below, the problem is potentially more general-how much should the agency be concerned about the potential for post-merger anticompetitive "foreclosure"- that is, the denial of access to important inputs to competing manufacturers? ${ }^{6}$

It is common in such a situation for competing manufacturers to contact the competition authority to express their concerns that if the raw material supplier comes under control of their manufacturing competitor, they will be discriminated against in supply in the future, whether with regard to price, service, or product availability. The reply from the merging firms will likely be that they would only be hurting themselves by treating a customer badly. How is one to evaluate the tradeoff that would face the newly merged, vertically integrated firm?

One analytical tool which could be presented to the competition authority by either party is a technique called the "vertical arithmetic" (Riordan and Salop 1995; Sibley and Doane 2002; CRA 2005; Moresi and Salop 2013). ${ }^{7}$ As with critical loss analysis and upward pricing pressure, the vertical arithmetic offers no magical

\footnotetext{
${ }^{5}$ As Pakes (2010) also points out, there could also be post-merger repositioning by one or both of the merging firms, and this could either increase or decrease the harm to competition that would otherwise take place.

${ }^{6}$ Of course, a proposed vertical merger could also raise the possibility of the foreclosure of access to downstream customers from an upstream competitor-what Riordan and Salop (1995) and Baker (2011) term "customer foreclosure". Or, as in the case analyzed by Baker, it could raise both issues simultaneously.

${ }^{7}$ An interesting application was the analysis by Ofcom, the UK communications regulator, of the incentives of the British Sky Broadcasting Group to deny access to premium channels to its downstream competitors such as Virgin Media. For the Ofcom analysis, see especially https:// www.ofcom.org.uk/_data/assets/pdf_file/0014/40451/annex8.pdf; for the Sky responses see https://www.ofcom.org.uk/_data/assets/pdf_file/0022/36616/1_sky.pdf and https://www.ofcom. org.uk/_data/assets/pdf_file/0021/50925/10_sky_annex_7.pdf. Application in a case brought by the FCC, the US telecommunications regulator, regarding similar issues in the proposed Comcast/ NBCU merger is discussed in Baker (2011) and Baker et al. (2011), while application in a case brought by the Antitrust Division of the Justice Department, the proposed acquisition of the direct broadcast satellite assets of the News Corporation and MCI by Primestar, is discussed in Salop et al. (1998) and Rubinfeld (2000).
} 
Fig. 2 A vertical merger

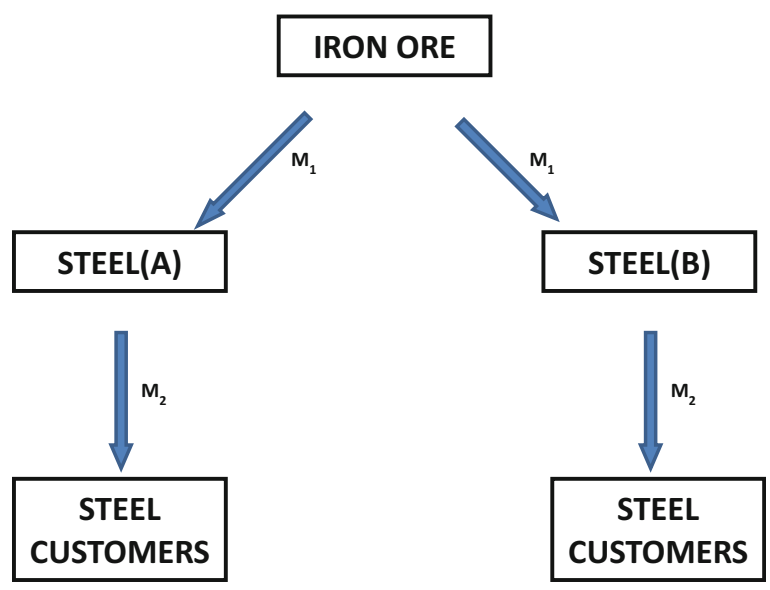

solutions, but it can be useful in focusing the competitive analysis on particular questions and issues.

Consider then a steel manufacturer A that is proposing to acquire its supplier of iron ore, as in Fig. 2. Assume that "steel" constitutes an antitrust product market; if the two firms both produced, say, "cold rolled steel", we would want to examine competition and foreclosure issues in that narrower potential product market instead or in addition to the broader one.

Let $\mathrm{M}_{1}$ equal the percentage profit margin earned by the iron ore company in its sales to steel manufacturers $\mathrm{A}$ and $\mathrm{B}$ (we assume equal margins for sales to the two customers) and $\mathrm{M}_{2}$ equal the percentage profit margin earned by steel manufacturers $\mathrm{A}$ and $\mathrm{B}$ in their sales to their own customers (also assumed equal across the two firms). Next we introduce $I_{B}$, the sales of iron ore to steel manufacturer $B-A$ 's rival-and $\mathrm{D}_{\mathrm{BA}}$, a downstream diversion ratio, the share of any sales of steel lost by steel manufacturer B that is recovered by steel manufacturer A (i.e., that would be recovered by the newly integrated firm after the merger).

Now consider the incentives of the newly integrated firm A in dealing with its steel manufacturer rival B. If the integrated firm refuses to supply iron ore to steel manufacturer $B$, it loses $I_{B} M_{1}$, its variable profits on those sales. However, from any steel sales diverted from the disadvantaged firm $\mathrm{B}$ to integrated firm $\mathrm{A}$ it gains $\mathrm{D}_{\mathrm{BA}} \mathrm{I}_{\mathrm{B}}\left(\mathrm{M}_{1}+\mathrm{M}_{2}\right)$, the variable profits both upstream and downstream of the increased steel sales by $\mathrm{A}$.

If $\mathrm{D}_{\mathrm{BA}}=0$ - if the none of the lost steel sales of firm $\mathrm{B}$ are recaptured by firm A - then the only result of A's decision to deny access to iron ore to B is the loss of its upstream variable profits $\mathrm{I}_{\mathrm{B}} \mathrm{M}_{1}$ - clearly an unprofitable strategy. On the other hand, if $\mathrm{D}_{\mathrm{BA}}=1$-if all of the lost steel sales of firm $\mathrm{B}$ are recaptured by firm $\mathrm{A}-$ then the gains and losses upstream cancel each other out, and the integrated firm would gain downstream variable profits $\mathrm{I}_{\mathrm{B}} \mathrm{M}_{2}$ from its decision to deny access to iron ore to B-clearly a profitable strategy. The breakeven point for the integrated firm's decision to deny access to its non-integrated rival is the point where $D_{B A}=M_{1}$ / 
$\left(\mathrm{M}_{1}+\mathrm{M}_{2}\right)$-if A gains less than this fraction of B's lost sales, foreclosure is unprofitable in this example.

The importance of the variable margins at the two stages of production is quickly apparent. If the iron ore firm has been earning a very large margin on its sales to steel manufacturers - if $M_{1}$ is high, especially relative to $M_{2}$ - then a vertical foreclosure strategy looks unlikely: the diversion ratio $\mathrm{D}_{\mathrm{BA}}$ would have to be very high to make such a strategy work, ceteris paribus. On the other hand, if the steel manufacturer A earns a very large margin on its sales to steel customers-if $\mathrm{M}_{2}$ is high, especially relative to $\mathrm{M}_{1}$ - then a vertical foreclosure strategy looks more likely: even a small $\mathrm{D}_{\mathrm{BA}}$ can make the strategy work.

So we are back to the importance of a familiar pair of figures: margins and a diversion ratio. We discussed both the usefulness and imperfections of measured firm margins in the previous section. As in that section, we next face the question of how to estimate the diversion ratio-again, in this case, the share of steel sales lost by steel manufacturer $\mathrm{B}$ that would be recaptured by its competitor steel manufacturer A.

As with the discussion of the use of diversion ratios in the analysis of upward pricing pressure, a first, default approximation is to use the firms' shares of the sales of steel. Maintaining the assumption that steel constitutes a product market, if firm A has $50 \%$ of the market and firm B $20 \%$, then a first approximation of the diversion ratio of sales from $B$ to A would be $50 /(100-20)=0.625$. We could then, as earlier, discount this figure by the percentage of $\mathrm{B}$ sales that might leave the steel market entirely were B to cease being a supplier-likely a small number.

At that point we would consider other factors that might render A's market share either an over- or an underestimate of this diversion ratio. If A's current capacity utilization in steel manufacturing is very high, it might not be able profitably to take over much of B's sales. If other rival steel manufacturers have plenty of excess capacity, they might be more aggressive in taking the diverted sales themselves. (Of course, we should also consider the possibility that the integrated firm would foreclose their iron ore supplies.) Similarly, there may be steel imports that are not currently in the market but could potentially be available to customers of B.

The investigation of these types of questions may inform the analyst's estimate of the relevant diversion ratio. Then this estimated ratio may be combined with the two margin estimates to reach a more informed analysis as to the potential of anticompetitive input foreclosure from the vertical merger. Going further, Moresi and Salop (2013) introduce several variants on GUPPI that may be used in the analysis of vertical mergers-vGUPPIs.

Finally, we should emphasize that the vertical arithmetic, like critical loss analysis and upward pricing pressure, does not answer all questions. Perhaps most importantly, we have not considered the possibility that foreclosure might not only disadvantage $\mathrm{B}$ and advantage $\mathrm{A}$ but also lead to a rise in the price of the downstream good, steel; the analysis presented above is thus conservative in its evaluation of the incentives for the merged firm to engage in foreclosure (Baker et al. 2011; Moresi and Salop 2013). We have not considered the possibility that other current or potential suppliers of iron ore might step in to supply B, thus rendering a foreclosure 
strategy ineffective in harming B in the first place. (This reminds us of the broader point that vertical mergers are likely to be harmful to competition only in the presence of significant market power at both levels.) We have also not considered the likelihood that there are other, more refined anticompetitive strategies available to the vertically integrated firm than the rather crude instrument of absolute input foreclosure (Moresi and Salop 2013). The vertical arithmetic outlined in this paper is only one of many tools that the analyst employs in assessing foreclosure incentives and effects.

\section{Conclusion}

Critical loss analysis, upward pricing pressure, and the vertical arithmetic are three investigative tools that have come into widespread use in the enforcement of competition law within the last two decades, reflecting the increased role played by economic analysis in competition policy and law enforcement. Their value resides not so much in their ability to answer enforcement questions by themselves as in their usefulness in isolating certain important issues to be addressed and questions to be answered by the investigator and the decision maker. Furthermore, experience suggests that debates concerning whether they are applicable to a particular investigation as well as which assumptions inherent in their use are or are not satisfied may be as informative as the outcomes of the use of the tools themselves.

The enforcement agency analyst who is adept at using these tools will be well prepared not only for his or her opportunity to educate decision makers, tribunals, and courts as to the most important issues and questions regarding an investigation, but also for the presentations and arguments of the companies and their attorneys and economic consultants who come before the agency to urge their own point of view.

Acknowledgment The author is grateful for comments on this presentation from colleagues at the Antimonopoly Committee of Ukraine and participants in the Conference on Institution Building of the Competition Authorities in South-East Europe (Belgrade, June 2016) and on a previous draft of the paper from Xiaoling Ang, Beth Armington, Tim Brennan, Jim Foster, Rui Huang, Atsuko Izumi, Šarūnas Pajarskas, and Steven Salop. The views expressed do not purport to reflect the views of the U.S. Department of Justice.

\section{References}

Amelio A, de la Mano M, Godinho de Mator M (2008) Ineos/Kerling merger: an example of quantitative analysis in support of a clearance decision. Comp Pol Newslett 1:65-69

Baker JB (2011) Comcast/NBCU: The FCC provides a roadmap for vertical merger analysis. Antitrust 25:36-41

Baker JB, Bykowsky M, DeGraba P, LaFontaine P, Ralph E, Sharkey W (2011) The year in economics at the FCC, 2010-11: protecting competition online. Rev Ind Organ 39:297-309 
Baltzopoulos A, Kim J, Mandorff M (2015) UPP analysis in five recent merger cases. Konkurrensverket Working Paper 2015, 3

Baumann MG, Godek PE (2009) Reconciling the opposing views of critical elasticity. GCP Antitrust Chron, Sept

Carlton D, Perloff J (2005) Modern industrial organization, 4th edn. Pearson/Addison-Wesley, Boston

Cheung L (2016) An empirical comparison between the upward pricing pressure test and merger simulation in differentiated product markets. J Comp Law Econ 12:701-734

CRA (2005) "Vertical arithmetic": the use of empirical evidence in vertical mergers. CRA Competition Memo, Charles River Associates. http://ecp.crai.com/publications/vertical_arithmetic. pdf

Farrell J, Shapiro C (2010a) Antitrust evaluation of horizontal mergers: an economic alternative to market definition. BE J Theor Econ 10:9

Farrell J, Shapiro C (2010b) Upward pricing pressure and critical loss analysis: response. CPI Antitrust J, Feb

Fisher FM (1987) On the misuse of the profit-sales ratio to infer monopoly power. RAND J Econ 18:384-396

Fisher FM, McGowan JJ (1983) On the misuse of accounting rates of return to infer monopoly profits. Am Econ Rev 73:82-97

Harris B, Simons J (1989) Focusing market definition: how much substitution is necessary? Res Law Econ 12:207-226

Hausman J, Moresi S, Rainey M (2011) Unilateral effects of mergers with general linear demand. Econ Lett 111:119-121

Hüschelrath K (2009) Critical loss analysis in market definition and merger control. Eur Compet J 5:757-794

Kaplow L, Shapiro C (2007) Antitrust. In: Polinsky AM, Shavell S (eds) Handbook of law and economics, vol 2. Elsevier, Philadelphia

Katz ML, Shapiro C (2003) Critical loss: let's tell the whole story. Antitrust Spring 49-56

Langenfeld J, Li W (2001) Critical loss analysis in evaluating mergers. Antitrust Bull 46:299-337

Moresi S (2010) The use of upward price pressure indices in merger analysis. Antitrust Source, Feb

Moresi S, Salop SC (2013) GUPPI: scoring unilateral pricing incentives in vertical mergers. Antitrust Law J 79:185-214

O'Brien DP, Wickelgren AL (2003) A critical analysis of critical loss analysis. Antitrust Law J 71:161-184

Pakes A (2010) Upward pricing pressure screens in the new merger guidelines: some pro's and con's. Presented at DG competition authority, Brussels. http://scholar.harvard.edu/files/pakes/ files/sdgcomp_0.pdf

Pittman R (2009) Who are you calling irrational? Marginal costs, variable costs, and the pricing practices of firms. https://www.justice.gov/atr/who-are-you-calling-irrational-marginal-costsvariable-costs-and-pricing-practices-firms

Riordan MH, Salop SC (1995) Evaluating vertical mergers: a post-chicago approach. Antitrust Law J 63:513-568

Rubinfeld DL (2000) The primestar acquisition of the News Corp./MCI direct broadcast satellite assets. Rev Ind Organ 16:193-209

Rybnicek J, Onken LC (2016) A hedgehog in fox's clothing? The misapplication of GUPPI analysis. Geo Mason Law Rev 23:1187-1203

Salop SC, Besen SM, Woodbury JR, Murdoch EJ (1998) An economic analysis of primestar's competitive behavior and incentives. Georgetown University Law Center and Charles River Associates

Schmalensee R (2009) Should new merger guidelines give UPP market definition? GCP. https:// www.competitionpolicyinternational.com/should-new-merger-guidelines-give-upp-marketdefinition/

Shapiro C (1996) Mergers with differentiated products. Antitrust Spring 23-30 
Shapiro C (2010) The 2010 horizontal merger guidelines: from hedgehog to fox in forty years. Antitrust Law J 77:701-759

Sibley DS, Doane MJ (2002) Raising the costs of unintegrated rivals: an analysis of Barnes \& Noble's proposed acquisition of Ingram book company. In: Slottje DJ (ed) Measuring market power. Elsevier, Amsterdam

Simons JJ, Coate MB (2014) United States v. H\&R Block: an illustration of the DOJ's new but controversial approach to market definition. J Comp Law Econ 10:543-580

Werden GJ (1996) A robust test for consumer welfare enhancing mergers among sellers of differentiated products. J Ind Econ 44:409-413

Werden GJ (2005) Beyond critical loss: tailored application of the hypothetical monopolist test. Comp Law 69-78

Werden GJ (2008) Beyond critical loss: properly applying the hypothetical monopolist test. GCP. https://www.competitionpolicyinternational.com/assets/ 0d358061e11f2708ad9d62634c6c40ad/Werden,\%20GCP\%20Feb-08(2).pdf

Willig R (1991) Merger analysis, industrial organization theory, and merger guidelines. Brook Pap Econ Activity Microecon 281-332

Open Access This chapter is licensed under the terms of the Creative Commons Attribution 4.0 International License (http://creativecommons.org/licenses/by/4.0/), which permits use, sharing, adaptation, distribution and reproduction in any medium or format, as long as you give appropriate credit to the original author(s) and the source, provide a link to the Creative Commons license and indicate if changes were made.

The images or other third party material in this chapter are included in the chapter's Creative Commons license, unless indicated otherwise in a credit line to the material. If material is not included in the chapter's Creative Commons license and your intended use is not permitted by statutory regulation or exceeds the permitted use, you will need to obtain permission directly from the copyright holder.

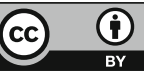

